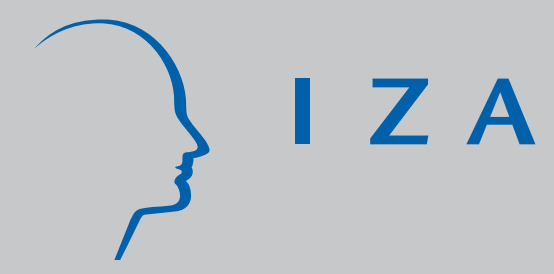

IZADP No. 3518

Is the Glass Ceiling Cracking? A Simple Test

Ting $\mathrm{Hu}$

Myeong-Su Yun

May 2008 


\title{
Is the Glass Ceiling Cracking? A Simple Test
}

\author{
Ting $\mathrm{Hu}$ \\ Tulane University \\ Myeong-Su Yun \\ Tulane University \\ and IZA \\ Discussion Paper No. 3518 \\ May 2008 \\ IZA \\ P.O. Box 7240 \\ 53072 Bonn \\ Germany \\ Phone: +49-228-3894-0 \\ Fax: +49-228-3894-180 \\ E-mail: iza@iza.org
}

Any opinions expressed here are those of the author(s) and not those of IZA. Research published in this series may include views on policy, but the institute itself takes no institutional policy positions.

The Institute for the Study of Labor (IZA) in Bonn is a local and virtual international research center and a place of communication between science, politics and business. IZA is an independent nonprofit organization supported by Deutsche Post World Net. The center is associated with the University of Bonn and offers a stimulating research environment through its international network, workshops and conferences, data service, project support, research visits and doctoral program. IZA engages in (i) original and internationally competitive research in all fields of labor economics, (ii) development of policy concepts, and (iii) dissemination of research results and concepts to the interested public.

IZA Discussion Papers often represent preliminary work and are circulated to encourage discussion. Citation of such a paper should account for its provisional character. A revised version may be available directly from the author. 
IZA Discussion Paper No. 3518

May 2008

\section{ABSTRACT}

\section{Is the Glass Ceiling Cracking? A Simple Test ${ }^{*}$}

It has been reported that there is dramatic increase of female workers into manager level jobs during last few decades in the US labor market. Using Standard \& Poor's Compustat ExecuComp database over 14 years (1992 - 2005), this paper examines whether the glass ceiling in the executive market has been substantially weakened measured by relative compensation by gender and female representation in the top rung of the executive market. Though the status of females in the executive market seems to have been improved, we cannot reject null hypothesis of no change when we test hypotheses whether the glass ceiling has significantly weakened. The results of the hypothesis tests suggest that there is still a long way ahead before gender equality is achieved and the glass ceiling is removed in the executive market.

JEL Classification: J15, J70

Keywords: glass ceiling, executive compensation, gender gap, top rank, hypothesis test

Corresponding author:

Myeong-Su Yun

Department of Economics

Tulane University

206 Tilton Hall

New Orleans, LA 70118

USA

E-mail: msyun@tulane.edu

\footnotetext{
*Authors wish to thank Ira N. Gang for his comments.
} 


\section{Introduction}

The glass ceiling is generally thought of as the transparent but real barrier which impedes qualified women and other minorities from advancing up the job ladder into high level management positions. As for any topic related to discrimination, it has been debated whether the glass ceiling exists or not. However, it is widely believed that a glass ceiling exists and that it operates substantially to exclude minorities and women from top levels of management. The existence of a glass ceiling has been studied extensively by examining representations of females in the top tier -- high paying and high skill -- labor market (e.g., manager market), and the relative compensation between men and women in the top tier labor market.

The executive market is one of the best examples of the high-paying and high skill top tier labor markets. ${ }^{1}$ If there exists a glass ceiling, it will definitely affect the representation of females in the executive market, and subsequently gender wage disparity among executives. ${ }^{2} \mathrm{~A}$ vast literature has found that the glass ceiling exists in executive market. For example, Bertrand and Hallock (2001) show women earn as much as 45\% less than men with the data from Standard \& Poor's (S\&P's hereafter) Compustat ExecuComp database from 1992 to 1997. Bell (2005) uses a similar approach and the same data set from 1992 to 2003 to get a significantly negative difference of $25.4 \%$ in pay for female executives. Yurtoglu and Zulehner (2007) find that female managers receive 24\% less in compensation than male colleagues using OSIRIS database from Bureau van Dyck; even after controlling various factors, gender disparity in compensation does not disappear --- female managers receive 6\% less.

\footnotetext{
1 Academia is another labor market researchers have studied for existence of glass ceiling, e.g., Malkiel and Malkiel (1973), Gander (1997), McDowell, Singell, and Ziliak (1999), and Ginther, and Hayes (2003).

2 The detrimental effect of glass ceiling is not limited to females in the top tier labor market. The existence of glass ceiling can also adversely affect females in lower level labor markets (Cohen and Huffman, 2007). See Blau and Kahn (2000) for trends in gender wage gap in overall labor market.
} 
Researchers have put great effort towards finding the sources of existing disparities in compensation and representation in the top tier labor market. They have asked to what extent the disparities reflect unobserved differences in productivity or prejudice against women (e.g., Wolfers, 2006). Another question, though less frequently asked, is whether the glass ceiling is cracking. Jacobs (1992) examines whether the dramatic increase in women's representations among managers between 1970 and 1988 was simply title inflation without commensurate pay or supervisory responsibility. He finds that women's increasing representation in management was not just a matter of reclassification since earnings gap narrows. Bertrand and Hallock (2001) explore the question whether glass ceiling is cracking in the executive market. They find the participation of female executives has been growing dramatically through the period 1992-1997, and conclude that female's increasing access to larger firms is the main reason for the cracking glass ceiling. These studies cite the increased proportion of females in the top rank jobs or decreasing disparities in compensation after controlling other relevant factors as the evidences of the weakening of the glass ceiling.

The goal of this paper is to test whether gender equality in high-paying and high-skill labor markets in terms of compensation and representation has statistically significantly improved over time. Unless there is statistically significant improvement in gender equality in the top tier labor market, particularly in the top executive labor market, it might be premature to celebrate the presumed weakening of the glass ceiling. The hypothesis test results undertaken in this paper cast a deep skepticism on the progress of gender equality and weakening of the glass ceiling in the executive market since we cannot reject the null hypothesis of no change in the degree of the glass ceiling during the 14 years, 1992-2005. 


\section{Data}

Our samples come from S\&P's Compustat ExecuComp database over 14 years ranging from 1992 to 2005. This database has been widely used in studying gender disparity in the high profile executive market (e.g., Bertrand and Hallock, 2001, and Burress and Zucca, 2004). This database has the richest information about the compensation and the job titles of several top executives for firms in S\&P 500. In addition, it contains useful information about firm characteristics such as market value, assets, sales and size of employees. This database is also one of very few which have been surveyed for long periods enabling us to study trends in the glass ceiling. An obvious drawback of this database is that very few executives report their age and tenure. ${ }^{3}$ Consequently, it limits the possibility of including executive's age and tenure into our regression and probit analyses. $^{4}$

The firms covered in this database are more than 1,600 in each year, except for year 1992 with 1237 firms. In total, 2,729 firms are surveyed over 14 years; of course, quite a few firms are surveyed in multiple years. ${ }^{5}$ The sample size per year is more than 8000 executives except for year 1992 when the sample size is 5,337 executives. The sample consists of 123,722 executives over 14 years: among them, only 5,459 executives are female (4.41\%) and the rest, 118,263 executives are male (95.59\%). ${ }^{6}$ Needless to say, male executives dominate the executive level jobs in US corporations. However, as shown in Figure 1, the proportion of women in the sample

\footnotetext{
${ }^{3}$ Lack of information on age is more severe than the lack of tenure information. We use a subset with tenure information for robustness testing.

${ }^{4}$ However, it may not be a fatal flaw. Since the population of this database comes from top managers in US corporations, both male and female managers are supposedly highly educated and motivated, therefore, both men and women are quite likely similar in their skills and productivities.

${ }^{5}$ We also utilize the fact that quite a few firms are repetitively surveyed over the years with firm fixed effects for a robustness check.

6 Of course, some executives appear in multiple times --- 30,016 executives are sampled at least once in the sample, 4.12 times on average. Among them, male and female executives are 28,337 (94.41\%) and 1,679 (5.59\%), respectively. This means that male executives are reappearing more frequently, 4.17 times (male) vs. 3.25 times (female). It may indicate that the duration of holding executive jobs is shorter among female executives relative to male executives.
} 
has consistently increased from $1.37 \%$ (1992) to $6.88 \%$ (2005). A more promising fact is that female representation has increased not only in the executive market in general but also in top rank jobs such as CEO, Chair, Vice-Chair, and President, from only $0.80 \%$ in 1992 to $4.31 \%$ in 2005. Similar progress is found when we look at the share of women in the top quintile compensation --- female share among the top quintile compensated executives -- rose from $0.56 \%$ in 1992 to $4.34 \%$ in 2005 . This may show that the status of women has gradually improved over last 14 years by the increase of women's percentage in either top rank jobs or top quintile compensated jobs.

Relative to the trend in female participation in the executive market, the trend in the disparity of compensation by gender is much less promising. Figure 2 shows the trend in the observed relative compensation where the male's compensation is normalized to $100 \%$. Compensation of female executives has been substantially lower than that of male colleagues. Though relative compensation has been fluctuated, for most of time it is less than $70 \%$ of the compensation of male executives. Only recently has the relative compensation of female to that of male increased over $70 \%$. Table 1 shows additional mean characteristics by gender for selected years. Female executives are more likely to be in smaller firms measured by assets, sales, market value and employment, which might be related to disparity in gender compensation gap. It also shows that the distribution of industry by gender is getting similar: ${ }^{7}$ The Duncan segregation index is 32.10 in 1992 and 15.88 in 2005 using 24 industry classifications. ${ }^{8}$

\footnotetext{
${ }^{7}$ Female executives concentrate in the industries such as education service, restaurants, healthcare, financial service and retail industries.

${ }^{8}$ Duncan segregation index is calculated as $D=0.5 \sum_{j=1}^{J}\left|M_{j}-F_{j}\right|$, where $M_{j}$ and $F_{j}$ are share of industry $j$ among male and female executives, respectively.
} 
In short, there seems to be a progress in female status in executive labor market according to descriptive statistics. Though the relative compensation does not show a persistent trend, the female representation shows consistent increases during 1992-2005. More women are not only in the executive market, but also in top rung of the market. Furthermore, increasing similarity between men and women in the executive market can be found in industrial distribution. Next section will examine whether seemingly improving female status in the executive labor market indicates significant cracking in glass ceiling when scrutinized under rigorous statistical tests.

\section{Testing Trends in the Glass Ceiling}

As a preliminary step in studying the trends in glass ceiling, we first examine whether there is substantial disparity between male and female executives even after controlling for a few covariates using regression (for compensation) and probit (for female representation). The specification includes a gender dummy variable as one of independent variables. The coefficient

of the gender dummy variable captures the adverse effect of being female in the executive market.

It has been noted that females are more likely to cluster in low-rank jobs relative to men. To capture female representation in the top rung of the executives, we use two dummy variables; the first is "top rank jobs" whose value is one if the title of the executive is CEO or Chairman or President or Vice Chair, and zero otherwise; the other is "top quintile compensation" whose value is one if the compensation is ranked in the top quintile of the pooled compensation distribution of both men and women in each year. To examine whether there is substantial disparity in female representation in the top rung of the executive market, we estimate two probit 
models with "top rank jobs" or "top quintile compensation" as a dependent variable and a gender dummy variable as one of the independent variables. The probit model is specified as follows;

$$
D_{t}=\Phi\left(\alpha_{t}+\text { Female }_{t} \delta_{t}+Z_{t} \beta_{t}\right),
$$

where $D$ is either dummy variable of "top rank jobs" or "top quintile compensation"; Female is a dummy variable, Female $=1$ if gender of executive is female, and zero, otherwise; $Z$ includes log of assets, log of sales, log of market value, and log of employees in addition to industry dummy variables; the dummy variable of "top rank jobs" is also included for probit analysis of "top quintile compensation"; $t$ is from year 1992 to year 2005.

We estimate the following regression for compensation;

$$
Y_{t}=a_{t}+\text { Female }_{t} d_{t}+X_{t} b_{t}+e_{t} \text {, }
$$

where $Y$ is $\log$ of total compensation where the value of compensation is converted to 1992 constant dollars; $X$ includes the same variables $Z$ contains for probit analysis of "top quintile compensation," that is, it contains a dummy variable of "top rank jobs" too.

The results of probit and regression estimations are shown in Table 2. As the last two columns show, the coefficients of the gender dummy variable, Female, is negative in every year. The coefficient of Female is not significant for every year when "top quintile compensation" is the dependent variable. However, the coefficient of Female is significant for every year when "top rank jobs" is the dependent variable. This indicates that female representation in the top rung in the executive market is substantially lower relative to male executives. Similar disparity is found when we look at compensation regression results. The coefficient of gender dummy variable, Female, is significantly negative during the time span, except for 1997 and 1998. This indicates that female executives receive substantially less than male counterparts in the executive market. We also estimate probit and regression models with a pooled sample over 
years by adding year fixed effects with the variables described in the specification for each year. As the last row shows, the coefficients of Female in regression and probit analyses are significantly negative.

Based on these preliminary results, we conclude that there is a glass ceiling in the executive labor market. We now turn our attention to trends in the glass ceiling. It is argued that the glass ceiling in executive level has begun to crack based on female's larger representation in the top level management, and their improved relative compensations supported by the decreased coefficient for the female dummy variable.

We employ two complementary statistical strategies for testing whether the glass ceiling has been cracking in recent years. The first strategy is testing whether the coefficient of Female has changed substantially when compared to earlier years. Since the coefficient of Female represents disparities between men and women, this test can show whether there is a systematic and significant change in the disparities over time. We apply the same binary comparison using estimates and variance from regressions and probits in each year. The test statistic for probit analysis of female representation can be constructed as follows;

$$
T=\left(\delta_{t}-\delta_{s}\right) / \sqrt{\operatorname{Var}\left(\delta_{t}\right)+\operatorname{Var}\left(\delta_{s}\right)},
$$

where $t$ and $s$ represent two different years; test statistic for regression can be similarly constructed.

The second test strategy is using difference-in-difference analysis after pooling the samples over the 14 years. We run regression and probit including dummy variable of Female, year dummy variables, and interaction terms of Female and year dummy variables, in addition to other controlling variables. The specification for probit and regression models can be shown as follows; 


$$
\begin{aligned}
& D=\Phi\left(\alpha+\text { Female }^{*} \delta+\sum_{t=1993}^{2005} \theta_{t} \text { Year }_{t}+\sum_{t=1993}^{2005} \gamma_{t} \text { Female }^{*} \text { Year }_{t}+Z \beta\right), \\
& Y=a+\text { Female }^{*} d+\sum_{t=1993}^{2005} q_{t} \text { Year }_{t}+\sum_{t=1993}^{2005} g_{t} \text { Female }^{*} \text { Year }_{t}+Z \beta+e
\end{aligned}
$$

where Year ${ }_{t}$ is a year dummy variable with $t$ is ranging from 1993 to 2005. By testing whether coefficients of the interaction terms, that is, $\gamma_{t}$ and $g_{t}$, are significantly different from zero, we can test whether there have been significant changes in gender disparity over time.

Tables 3-1, 3-2 and 3-3 show test results for binary comparison based on the estimates of Female reported in Table 2. Comparing the coefficients of Female in the regression of compensation may shed light to the trends in the glass ceiling --- whether the adverse effect of being female has decreased substantially in recent years. It seems that there might be decreases in gender disparity in compensation until the late 1990s, then increases again in recent years. The coefficients of Female in the probit of "top rank jobs" show that the gender disparities may have decreased more or less consistently. However, the coefficients of Female in the probit of "top quintile compensation" show that the gender disparities have become significant only recently. It is hard to obtain a clean picture of trends in the glass ceiling in the executive market; decreasing and increasing in compensation, decreasing in top rank jobs, and increasing recently in top quintile compensation. Using the first strategy of our statistical tests, we will examine whether the different pattern of trends in glass ceiling can be verified with statistical rigorousness.

The test results of the binary comparison of estimates of Female, reported in Table 3, do not show any substantial change in gender equality, that is, no significant cracking in the glass ceiling. The year-by-year estimates of Female for compensation show that virtually no significant changes except for 1997 and 1998. This might be potentially interpreted as 
weakening until late 1990s, and then restoration of the glass ceiling, but it is also possible that the two years, 1997 and 1998, are outliers. ${ }^{9}$

The binary comparisons of Female estimates in the probit of "top rank jobs" do not show significant changes over time except for differences between the mid-90s (1994, 1995 and 1997), and last two years of the sample (2004 and 2005), though the estimates have more or less consistently decreased over time. The binary comparisons of Female estimates in the probit of "top quintile compensation" show virtually no significant changes over time. In short, binary comparisons cannot support any statistically significant improvement in gender equality or that cracking of the glass ceiling is statistically significant.

Further, the results from the difference-in-difference test strategy, reported in Table 4, clearly indicate that a crack in the glass ceiling has never occurred. In our result, none of interaction terms are significant. In other words, the difference-in-difference estimates of the interaction terms show that basically there have been no significant changes in the glass ceiling whether studied using regression of compensation or probit analyses of "top rank jobs" or "top quintile compensation."

In short, our test results based on two statistical test strategies show that the talk that there might be weakening of the glass ceiling and reducing gender disparities are more or less a myth which might look more promising in the late 1990s but have not been materialized in the new century. ${ }^{10}$

\footnotetext{
${ }^{9}$ Note that Bertrand and Hallock (2001) study the trend of glass ceiling using the same database ranging from 1992 to 1997. This different sample period may explain their more optimistic view on trend in the glass ceiling.

${ }^{10}$ For robustness tests, we have examined two other versions; one is using the same sample, but including firm fixed effects. For including firm fixed effects, all firm characteristics variables such as market value, assets, etc, and industry dummy variables are excluded. The other is using a subset of the sample where the information of tenure is available, and adding tenure into the model specification. Two versions show qualitatively similar results of no significant cracking in the glass ceiling reported in this paper. The results of the robustness tests are available from authors upon request.
} 


\section{Conclusion}

The glass ceiling is a barrier against women's advancement into the top rung in the high-paying and high-skill labor market such as the executive market. The majority of papers have studied whether there exists a glass ceiling and, if exists, what factors cause the glass ceiling. This paper rigorously tests whether trends in the glass ceiling have significantly begun to crack where the glass ceiling is approached from various aspects, relative compensation and female representation in top rung in the executive labor market using S\&P Compustat ExecuComp database over 14 years, from 1992 to 2005.

Judging from relative compensation and increasing female representation in the top rung in the executive market, researchers are optimistic and conclude that, though not as fast and widespread as hoped, the weakening and cracking glass ceiling is not just a false hope but has some substances (Jacobs, 1992 and Bertrand and Hallock, 2001). However, the improvement of relative compensation does not continue in recent years. Furthermore the results of rigorous tests on trends in the glass ceiling using two statistical test strategies cast further doubts on cracking the glass ceiling in a significant manner. It indicates how strong and thick the glass ceiling is, hence, how arduous a task it is to achieve greater gender equality and cracking the glass ceiling. 


\section{References}

Bell, Linda A. (2005), “Women-Led Firms and the Gender Gap in Top Executive Jobs,” IZA DP No. 1689.

Bertrand, Marianne and Kevin F. Hallock (2001), “The Gender Gap in Top Corporate Jobs,” Industrial and Labor Relations Review, 55: 3-21.

Blau, Francine D. and Lawrence M. Kahn (2000), “Gender Differences in Pay,” Journal of Economic Perspectives, 14(4): 75-99.

Burress, Joanne H. and Linda J. Zucca (2004), "The Gender Equity Gap in Top Corporate Executive Positions,” Mid-American Journal of Business, 19(1):54-62.

Cohen, Philip N. and Matt L. Huffman (2007), "Working for the Woman? Female Mangers and the Gender Wage Gap," American Sociological Review, 72(5): 681-704.

Gander, James P. (1997), “Gender-based Faculty Pay Differences in Academe: A Reduced-form Approach,” Journal of Labor Research, 18(3):451-461.

Ginther, Donna K., and Kathy J.Hayes (2003), "Gender Differences in Salary and Promotion for Faculty in the Humanities 1977-95,” Journal of Human Resources, 38(1):34-73

Jacobs, Jerry A. (1992), "Women's Entry into Management: Trends in Earnings, Authority, and Values among Salaried Mangers," Administrative Science Quarterly, 37(2):282-301.

Malkiel, Burton G. and Judith A. Malkiel (1973), "Male-Female Pay Differentials in Professional Employment,” American Economic Review, 63(4): 693-705

McDowell, John M., Larry D. Singell Jr. and James P. Ziliak (1999), “Cracks in the Glass Ceiling: Gender and Promotion in the Economics Profession," American Economic Review, 89(2): 392-3.

Wolfers, Justin (2006), “Diagnosing Discrimination: Stock Returns and CEO Gender,” Journal of the European Economic Association, 4 (2/3): 531-541.

Yurtoglu, Burcin B. and Christine Zulehner (2007), "The Gender Wag Gap in Top Corporate Jobs is Still There," SSRN ID. 996224. 
Table 1. Mean Characteristics of S\&P's Compustat ExecuComp database

\begin{tabular}{|c|c|c|c|c|c|c|c|c|}
\hline & \multicolumn{2}{|c|}{1992} & \multicolumn{2}{|c|}{1995} & \multicolumn{2}{|c|}{2000} & \multicolumn{2}{|c|}{2005} \\
\hline & Male & Female & Male & Female & Male & Female & Male & Female \\
\hline Number of Observations & 5264 & 73 & 8603 & 242 & 8796 & 477 & 7825 & 578 \\
\hline \multicolumn{9}{|l|}{ Firm Size Variables } \\
\hline Assets & 4563.89 & 2244.62 & 4188.05 & 2238.85 & 5903.70 & 4291.52 & 8620.29 & 11213.40 \\
\hline Sales & 2177.05 & 735.38 & 2056.66 & 1029.84 & 2574.04 & 2135.34 & 3236.28 & 3048.46 \\
\hline Market Value & 1949.92 & 879.81 & 2170.35 & 1166.5 & 4516.26 & 3717.53 & 4365.21 & 4637.75 \\
\hline Employment & 17.53 & 5.52 & 15.98 & 8.89 & 18.28 & 18.87 & 20.95 & 20.27 \\
\hline \multicolumn{9}{|l|}{ Industry Composition } \\
\hline Tires \& Rubber & 2.26 & 1.37 & 2.30 & 0.83 & 1.71 & 1.05 & 1.84 & 1.04 \\
\hline Semiconductors & 1.35 & 0.00 & 1.86 & 0.00 & 4.18 & 1.47 & 4.60 & 2.08 \\
\hline Steel & 8.66 & 0.00 & 9.16 & 1.65 & 7.29 & 4.40 & 6.81 & 3.81 \\
\hline Oil \& Gas Drilling & 5.95 & 2.74 & 5.14 & 2.89 & 5.05 & 1.89 & 5.19 & 2.60 \\
\hline Building Products & 9.69 & 2.74 & 9.49 & 2.48 & 8.74 & 3.56 & 9.05 & 5.54 \\
\hline Home furnishing Retail & 5.89 & 16.44 & 6.04 & 13.22 & 5.55 & 13.84 & 5.44 & 11.76 \\
\hline Air Freight \& Logistics & 3.08 & 1.37 & 2.62 & 2.48 & 2.42 & 1.68 & 2.35 & 1.73 \\
\hline Distillers \& Vintners & 2.72 & 0.00 & 3.10 & 0.41 & 2.93 & 2.94 & 2.67 & 2.42 \\
\hline Food Retail & 2.20 & 1.37 & 2.13 & 1.65 & 1.30 & 1.26 & 1.35 & 1.21 \\
\hline Electronic Equipment Manufacturers & 4.50 & 5.48 & 6.52 & 4.13 & 8.36 & 7.13 & 7.87 & 6.75 \\
\hline Life \& Health Insurance & 3.95 & 4.11 & 3.08 & 3.72 & 3.12 & 1.68 & 3.67 & 3.29 \\
\hline Regional Banks & 7.56 & 4.11 & 4.45 & 4.13 & 5.35 & 5.24 & 5.37 & 6.23 \\
\hline Industrial REITs & 0.19 & 0.00 & 0.17 & 0.00 & 0.97 & 0.21 & 2.10 & 1.90 \\
\hline Other Diversified Financial Services & 2.39 & 2.74 & 2.73 & 1.24 & 2.71 & 2.52 & 2.67 & 2.94 \\
\hline Home Entertainment Software & 2.83 & 6.85 & 3.94 & 3.72 & 8.05 & 9.64 & 7.57 & 7.44 \\
\hline \multicolumn{9}{|l|}{ Integrated Telecommunication } \\
\hline Services & 1.92 & 2.74 & 1.48 & 2.89 & 1.22 & 1.26 & 1.05 & 1.56 \\
\hline Multi-Utilities & 10.18 & 15.07 & 7.76 & 9.50 & 5.41 & 6.08 & 5.10 & 7.09 \\
\hline Leisure Products & 5.30 & 6.85 & 6.03 & 12.81 & 5.39 & 6.50 & 4.93 & 4.33 \\
\hline \multicolumn{9}{|l|}{ Human Resource \& Employment } \\
\hline Services & 3.86 & 2.74 & 4.25 & 4.13 & 3.37 & 5.03 & 3.46 & 3.81 \\
\hline Health Care Equipment & 5.30 & 8.22 & 6.29 & 10.74 & 6.13 & 8.39 & 6.35 & 6.92 \\
\hline Movies \& Entertainment & 3.02 & 4.11 & 2.88 & 4.96 & 2.42 & 2.94 & 2.16 & 3.29 \\
\hline
\end{tabular}




\begin{tabular}{|c|c|c|c|c|c|c|c|}
\hline Restaurants & 2.66 & 2.74 & 4.05 & 4.55 & 3.75 & 5.45 & 3.99 \\
\hline Life Sciences Tools \& Services & 3.51 & 8.22 & 3.56 & 5.79 & 3.58 & 3.98 & 3.65 \\
\hline Personal Products & 1.03 & 0.00 & 0.96 & 2.07 & 1.02 & 1.89 & 0.75 \\
\hline Segregation Index & \multicolumn{2}{|c|}{32.10} & \multicolumn{2}{|c|}{28.11} & \multicolumn{2}{|c|}{19.11} & 15.88 \\
\hline
\end{tabular}

Note: Assets, Sales and Market Value are in 1992 constant billion dollars. Employment is in thousands. 
Table 2. Gender Disparity in Compensation and Representation in Top Rung of Executive Labor Market

Log-Compensation

$\begin{array}{ccc} & \text { Estimate } & \text { S.E. } \\ 1992 & -0.225^{* *} & 0.090 \\ 1993 & -0.171^{* * *} & 0.058 \\ 1994 & -0.197^{* * *} & 0.060 \\ 1995 & -0.161^{* * *} & 0.044 \\ 1996 & -0.156^{* * *} & 0.044 \\ 1997 & -0.051 & 0.041 \\ 1998 & -0.060 & 0.040 \\ 1999 & -0.107^{* * *} & 0.040 \\ 2000 & -0.077^{* *} & 0.038 \\ 2001 & -0.151^{* * *} & 0.043 \\ 2002 & -0.181^{* * *} & 0.033 \\ 2003 & -0.089^{* * *} & 0.027 \\ 2004 & -0.132 * * * & 0.028 \\ 2005 & -0.105^{* * *} & 0.026 \\ \text { Pooled } & -0.121^{* * *} & 0.011\end{array}$

Top Rank Jobs

$\begin{array}{lc}\text { Estimate } & \text { S.E. } \\ -0.528 * * * & 0.154 \\ -0.491 * * * & 0.114 \\ -0.700 * * * & 0.010 \\ -0.726 * * * & 0.092 \\ -0.602 * * * & 0.079 \\ -0.700 * * * & 0.073 \\ -0.605 * * * & 0.071 \\ -0.606 * * * & 0.066 \\ -0.621 * * * & 0.064 \\ -0.609 * * * & 0.061 \\ -0.603 * * * & 0.060 \\ -0.552 * * * & 0.058 \\ -0.498 * * * & 0.056 \\ -0.491 * * * & 0.058 \\ -0.586 * * * & 0.019\end{array}$

Top Quintile Compensation

Estimate S.E.

$\begin{array}{cc}-0.502 * & 0.267 \\ -0.239 & 0.174 \\ -0.132 & 0.171 \\ -0.188 & 0.152 \\ -0.186 & 0.127 \\ -0.073 & 0.113 \\ -0.092 & 0.103 \\ -0.188 * * & 0.093 \\ -0.140 & 0.088 \\ -0.070 & 0.086 \\ -0.218 * * & 0.090 \\ -0.246 * * * & 0.088 \\ -0.164 * & 0.091 \\ -0.293 * * * & 0.090 \\ -0.173 * * * & 0.028\end{array}$

Note: $* * *, * *$, and $*$ denote significance at the 1,5 and 10 percent respectively. The dependent variable for the regression and probit are log compensation, and a binary variable of top rank jobs and top quintile compensation, respectively. Independent variables include firm characteristics -- market value of the firm, sales, assets, and employment size -- and industry dummy variables in addition to the gender variable of Female. Regression of compensation and probit analysis for top quintile compensation also include a dummy variable of top rank as one of independent variables. Pooled specification includes year fixed effects in addition to all included variables in specification for each year. 
Table 3-1. Binary Comparison of Regression Estimates of Female

$\begin{array}{ccccccccccccccc}\text { Year } & 1992 & 1993 & 1994 & 1995 & 1996 & 1997 & 1998 & 1999 & 2000 & 2001 & 2002 & 2003 & 2004 & 2005 \\ 1992 & 0 & 0 & 0 & 0 & 0 & * & * & 0 & 0 & 0 & 0 & 0 & 0 & 0 \\ 1993 & 0 & 0 & 0 & 0 & 0 & * & 0 & 0 & 0 & 0 & 0 & 0 & 0 & 0 \\ 1994 & 0 & 0 & 0 & 0 & 0 & * * & * & 0 & * & 0 & 0 & 0 & 0 & 0 \\ 1995 & 0 & 0 & 0 & 0 & 0 & * & * & 0 & 0 & 0 & 0 & 0 & 0 & 0 \\ 1996 & 0 & 0 & 0 & 0 & 0 & * & 0 & 0 & 0 & 0 & 0 & 0 & 0 & 0 \\ 1997 & * & * & * * & * & * & 0 & 0 & 0 & 0 & * & * * & 0 & 0 & 0 \\ 1998 & * & 0 & * & * & 0 & 0 & 0 & 0 & 0 & 0 & * * & 0 & 0 & 0 \\ 1999 & 0 & 0 & 0 & 0 & 0 & 0 & 0 & 0 & 0 & 0 & 0 & 0 & 0 & 0 \\ 2000 & 0 & 0 & * & 0 & 0 & 0 & 0 & 0 & 0 & 0 & * * & 0 & 0 & 0 \\ 2001 & 0 & 0 & 0 & 0 & 0 & * & 0 & 0 & 0 & 0 & 0 & 0 & 0 & 0 \\ 2002 & 0 & 0 & 0 & 0 & 0 & * * & * * & 0 & * * & 0 & 0 & * * & 0 & * \\ 2003 & 0 & 0 & 0 & 0 & 0 & 0 & 0 & 0 & 0 & 0 & * * & 0 & 0 & 0 \\ 2004 & 0 & 0 & 0 & 0 & 0 & 0 & 0 & 0 & 0 & 0 & 0 & 0 & 0 & 0 \\ 2005 & 0 & 0 & 0 & 0 & 0 & 0 & 0 & 0 & 0 & 0 & * & 0 & 0 & 0\end{array}$

Note: $* * *, * *$, and $*$ denote significance at the 1,5 and 10 percent respectively. 
Table 3-2. Binary Comparison of Estimates of Female in Probit Analysis for Top Rank Jobs

$\begin{array}{ccccccccccccccc}\text { Year } & 1992 & 1993 & 1994 & 1995 & 1996 & 1997 & 1998 & 1999 & 2000 & 2001 & 2002 & 2003 & 2004 & 2005 \\ 1992 & 0 & 0 & 0 & 0 & 0 & 0 & 0 & 0 & 0 & 0 & 0 & 0 & 0 & 0 \\ 1993 & 0 & 0 & 0 & 0 & 0 & 0 & 0 & 0 & 0 & 0 & 0 & 0 & 0 & 0 \\ 1994 & 0 & 0 & 0 & 0 & 0 & 0 & 0 & 0 & 0 & 0 & 0 & 0 & * & * \\ 1995 & 0 & 0 & 0 & 0 & 0 & 0 & 0 & 0 & 0 & 0 & 0 & 0 & * * & * * \\ 1996 & 0 & 0 & 0 & 0 & 0 & 0 & 0 & 0 & 0 & 0 & 0 & 0 & 0 & 0 \\ 1997 & 0 & 0 & 0 & 0 & 0 & 0 & 0 & 0 & 0 & 0 & 0 & 0 & * & * \\ 1998 & 0 & 0 & 0 & 0 & 0 & 0 & 0 & 0 & 0 & 0 & 0 & 0 & 0 & 0 \\ 1999 & 0 & 0 & 0 & 0 & 0 & 0 & 0 & 0 & 0 & 0 & 0 & 0 & 0 & 0 \\ 2000 & 0 & 0 & 0 & 0 & 0 & 0 & 0 & 0 & 0 & 0 & 0 & 0 & 0 & 0 \\ 2001 & 0 & 0 & 0 & 0 & 0 & 0 & 0 & 0 & 0 & 0 & 0 & 0 & 0 & 0 \\ 2002 & 0 & 0 & 0 & 0 & 0 & 0 & 0 & 0 & 0 & 0 & 0 & 0 & 0 & 0 \\ 2003 & 0 & 0 & 0 & 0 & 0 & 0 & 0 & 0 & 0 & 0 & 0 & 0 & 0 & 0 \\ 2004 & 0 & 0 & * & * * & 0 & * & 0 & 0 & 0 & 0 & 0 & 0 & 0 & 0 \\ 2005 & 0 & 0 & * & * * & 0 & * & 0 & 0 & 0 & 0 & 0 & 0 & 0 & 0\end{array}$

Note: $* * *, * *$, and $*$ denote significance at the 1,5 and 10 percent respectively. 
Table 3-3. Binary Comparison of Estimates of Female in Probit Analysis for Top Quintile Compensation

$\begin{array}{ccccccccccccccc}\text { Year } & 1992 & 1993 & 1994 & 1995 & 1996 & 1997 & 1998 & 1999 & 2000 & 2001 & 2002 & 2003 & 2004 & 2005 \\ 1992 & 0 & 0 & 0 & 0 & 0 & 0 & 0 & 0 & 0 & 0 & 0 & 0 & 0 & 0 \\ 1993 & 0 & 0 & 0 & 0 & 0 & 0 & 0 & 0 & 0 & 0 & 0 & 0 & 0 & 0 \\ 1994 & 0 & 0 & 0 & 0 & 0 & 0 & 0 & 0 & 0 & 0 & 0 & 0 & 0 & 0 \\ 1995 & 0 & 0 & 0 & 0 & 0 & 0 & 0 & 0 & 0 & 0 & 0 & 0 & 0 & 0 \\ 1996 & 0 & 0 & 0 & 0 & 0 & 0 & 0 & 0 & 0 & 0 & 0 & 0 & 0 & 0 \\ 1997 & 0 & 0 & 0 & 0 & 0 & 0 & 0 & 0 & 0 & 0 & 0 & 0 & 0 & 0 \\ 1998 & 0 & 0 & 0 & 0 & 0 & 0 & 0 & 0 & 0 & 0 & 0 & 0 & 0 & 0 \\ 1999 & 0 & 0 & 0 & 0 & 0 & 0 & 0 & 0 & 0 & 0 & 0 & 0 & 0 & 0 \\ 2000 & 0 & 0 & 0 & 0 & 0 & 0 & 0 & 0 & 0 & 0 & 0 & 0 & 0 & 0 \\ 2001 & 0 & 0 & 0 & 0 & 0 & 0 & 0 & 0 & 0 & 0 & 0 & 0 & 0 & * \\ 2002 & 0 & 0 & 0 & 0 & 0 & 0 & 0 & 0 & 0 & 0 & 0 & 0 & 0 & 0 \\ 2003 & 0 & 0 & 0 & 0 & 0 & 0 & 0 & 0 & 0 & 0 & 0 & 0 & 0 & 0 \\ 2004 & 0 & 0 & 0 & 0 & 0 & 0 & 0 & 0 & 0 & 0 & 0 & 0 & 0 & 0 \\ 2005 & 0 & 0 & 0 & 0 & 0 & 0 & 0 & 0 & 0 & * & 0 & 0 & 0\end{array}$

Note: $* * *, * *$, and $*$ denote significance at the 1,5 and 10 percent respectively. 
Table 4. Estimates of Interaction Terms of Female and Year Dummy Variables

Log-Compensation

$\begin{array}{cccc}\text { Female* Year } & \text { Estimate } & \text { S.E. } & \text { Estimate } \\ 1993 & 0.060 & 0.112 & 0.043 \\ 1994 & -0.000 & 0.112 & -0.167 \\ 1995 & 0.021 & 0.104 & -0.196 \\ 1996 & 0.041 & 0.104 & -0.064 \\ 1997 & 0.136 & 0.103 & -0.131 \\ 1998 & 0.117 & 0.102 & -0.070 \\ 1999 & 0.075 & 0.102 & -0.070 \\ 2000 & 0.110 & 0.102 & -0.081 \\ 2001 & 0.033 & 0.103 & -0.066 \\ 2002 & 0.007 & 0.100 & -0.062 \\ 2003 & 0.092 & 0.098 & -0.017 \\ 2004 & 0.048 & 0.098 & 0.036 \\ 2005 & 0.080 & 0.098 & 0.040\end{array}$

Top Rank Jobs

S.E.

0.191

0.183

0.179

0.173

0.170

0.169

0.168

0.167

0.166

0.165

0.164

0.164

0.165
Top Quintile Compensation

Estimate

S.E.

$\begin{array}{ll}0.223 & 0.324 \\ 0.283 & 0.316 \\ 0.207 & 0.307 \\ 0.266 & 0.296 \\ 0.368 & 0.290 \\ 0.324 & 0.287 \\ 0.294 & 0.284 \\ 0.313 & 0.282 \\ 0.346 & 0.281 \\ 0.201 & 0.283 \\ 0.173 & 0.281 \\ 0.221 & 0.282 \\ 0.096 & 0.282\end{array}$

Note: No estimates are significant even at $10 \%$ significance level. The dependent variable for the regression and probit are log compensation and a binary variable of top rank and top quintile compensation. Independent variables include firm characteristics -market value of the firm, sales, assets, and employment size -- and industry dummy variables in addition to the gender variable of Female, year dummy variables and the interaction terms of Female and year dummy variables. Regression of compensation and probit analysis for top quintile compensation also include a dummy variable of top rank as one of independent variables. 
Figure 1.Female Representation in Executive Market (\%)

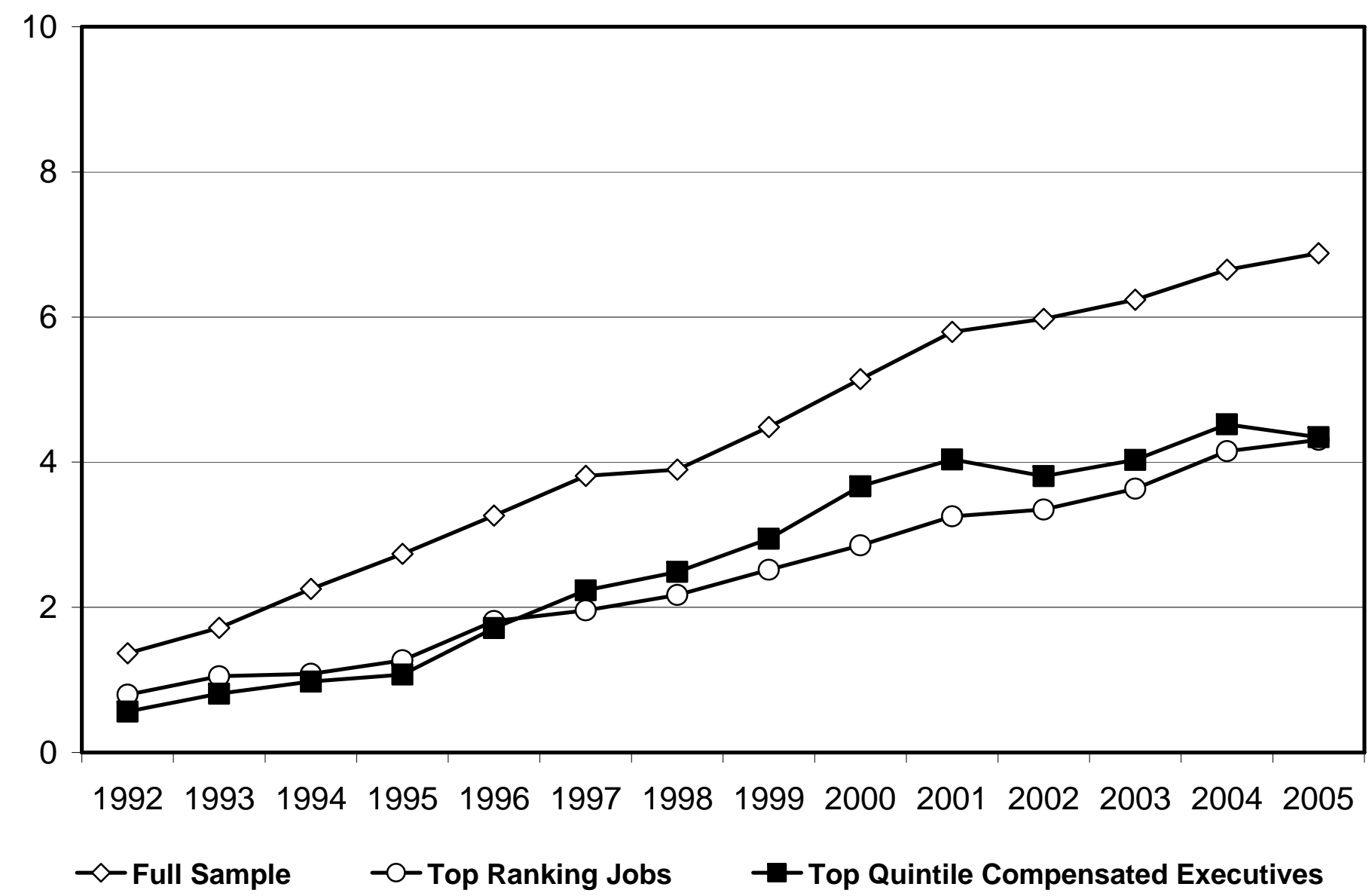


Figure 2. Relative Female Compensation (Male Compensation = 100\%)

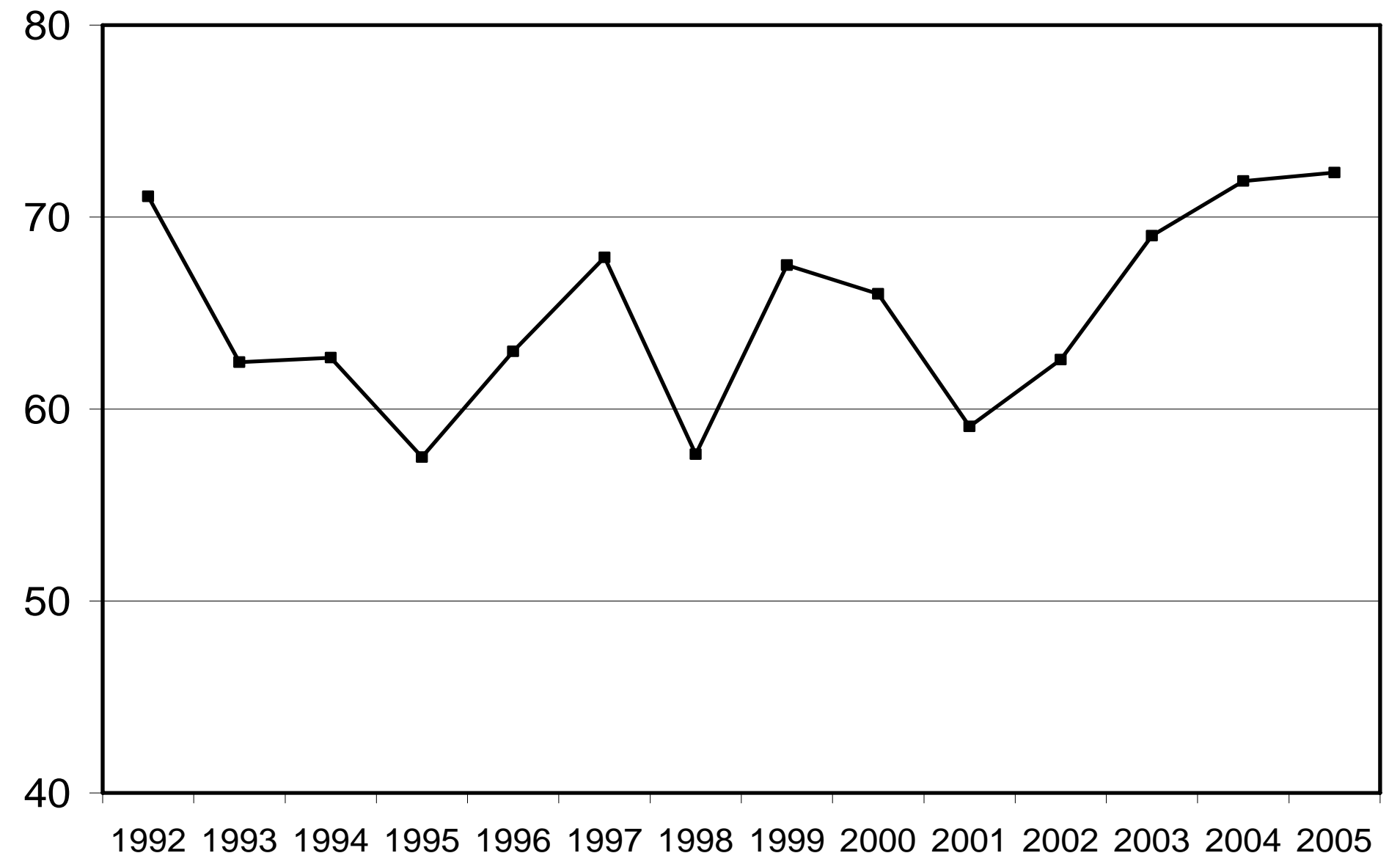

